\title{
DEN TAVSE VENSTREFLØJSPOLITIK
}

\author{
At være og at gøre tavs
}

\author{
TORBEN BECH DYRBERG
}

I modsætning til liberale og konservative er venstreorienterede påfaldende tavse. Det er blevet bemærket af flere politikere som Søren Espersen og Per Stig Møller, der begge har efterlyst modspil, og i forsommeren 2011 annoncerede dagbladet Politiken ligefrem efter unge venstrefløjsdebattører. Der kan være flere grunde til denne tavshed. Men én, der forekommer iøjnefaldende, er, at man er i vildrede med hensyn til, hvad det er man vil, efter at fordums universalistiske forestillinger om socialisme og emancipation har mistet pusten. Dette hænger sammen med, at højre/venstreorientering ikke længere er i stand til at præge og indramme politisk orientering. Som modtræk til desorientering er der en tendens blandt venstreorienterede til at holde fast i en ven/fjende-skematik for at dyrke sin modstandsidentitet, hvilket er kommet til udtryk i moralisering og kulturrelativisme. Men prisen for at bevare denne identitet har været, at evnen til principiel stillingtagen er blevet svækket. Det indebærer, at man indstiller kritikken af holdninger, man plejede at være modstander af, når det er venner eller fjendens fjender, der ytrer dem, og at man vil censurere politiske modstandere, dvs. knægte deres ytringsfrihed, selvom man kan være enig med dem.

Jeg vil analysere disse to aspekter af tavshed, der bliver legitimeret ved, at man forskyder spørgsmålet om ytringsfrihed fra politisk ret til moralsk indlevelse, moraliserer og polariserer det politiske klima i godt/ondt og dermed stigmatiserer modparten samt opfordrer til selvcensur og censur af, hvad man opfatter som politisk anløbent. Formålet er i alle tilfælde at beskytte svage grupper i tolerancens navn. Dette vil i forbindelse med karikaturkrisen, der tog afsæt i dagbladet Jyllands-Postens Muhammed-tegninger publiceret den 30. september 2005, og efterfølgende diskussioner af racismeparagraffen ${ }^{1}$ blive analyseret ud fra indlæg i nyhedsmedier de senere år, der i højere grad end akademiske tekster kan få fat $\mathrm{i}$ både stemningen i debatten, og hvordan man orienterer sig. Genstandsfeltet er altså politisk kultur. 


\section{Venstreorienteredes tavshed}

Tavshed kan have utallige årsager og virkninger. Den kan være forårsaget af afsky, arrogance, ligegyldighed, befippelse, sorg, eller fordi man er bevæget eller omvendt er lidenskabsløs. Og den kan have de mest forskelligartede virkninger som at udvise foragt, mistænksomhed eller samtykke. Den tavshed, jeg vil beskæftige mig med her, illustrerer det problem, brede kredse på venstrefløjen står over for i disse årtier, hvor den universalistiske og emancipatoriske kritik af kapitalisme og imperialisme er blevet afløst af kulturrelativismens kritik af modernitet og Vesten. Det har medført, at man de facto har støttet radikale islamister som f.eks. under karikaturkrisen. Det overordnede hensyn synes at have været at pleje sin modstandsidentitet ved at støtte dem, der er imod magten, og som automatisk tildeles status som udstødte og svage, dvs. ofre.

Dette har indebåret, at man er tavs om forhold, man plejede at kritisere. Man er stadig indigneret over homofobi og kvindeundertrykkelse, men kun i det omfang, det ikke kolliderer med indignationen over racisme, der for det meste identificeres med ,islamofobi“. Det, jeg vil se på her, er, hvordan venstreorienterede er tavse - en tavshed, der er betinget af tre nært beslægtede forhold: relativisme, politisk defaitisme og modstandsidentitet.

Relativisme er vævet sammen med diverse posttrends' insisteren på, at alt er kontekst. Politisk har det indebåret, at relativisme er blevet lanceret som tolerance og forståelse for anderledes kulturer. Kulturen bliver individets skæbne, hvilket ikke bare udhuler højre/venstreorientering, men også individualitet og ansvarspådragelse. Men indifference over for undertrykkelse er indbygget i kulturrelativisme, hvilket indebærer, at det kan være svært at trække grænsen mellem solidaritet og berøringsangst.

Politisk defaitisme slog for alvor igennem i slutningen af 1980'erne og blev flankeret af to begivenheder af global betydning: murens fald og det iranske præsteskabs dødsdom (fatwa) mod den indisk-engelske forfatter Salman Rushdie. De gamle modsætninger mellem kapitalisme og socialisme blev afløst af spændinger af kulturelt tilsnit som sprog, etnicitet, religion og nationalitet. Venstrefløjen var her konfronteret med konflikter, hvis intensitet og dynamik var den fremmed.

Venstreorientering hænger sammen med at være en progressiv oppositionel minoritet og dermed det modsatte af at være reaktionær, konform og almindelig. Man er derfor udstyret med en latent modstandsidentitet, der kan finde udtryk i vidt forskellige politiske budskaber. Det afgørende er ikke indholdet i disse, men derimod den position, man ønsker at repræsentere, nemlig dem, der er ude og nede, dvs. stigmatiserede og magtesløse. 
At være venstreorienteret forstår jeg bredt som dem, der ser sig selv som socialister, progressive og tilmed venstre- eller socialliberale samt kulturradikale, der vender sig imod det konforme og borgerlige. Det er selvsagt en broget forsamling, men på trods heraf vil jeg alligevel mene, det kan forsvares at generalisere nogle udviklingstræk på venstrefløjen, der i de seneste årtier har overtaget udsyn, der tidligere blev forbundet med højreorientering. Det er kommet til udtryk i en skeptisk indstilling til fremskridt, modernitet, rationalitet, sandhed og frihed, og det er kommet til udtryk i tavshed, der eufemistisk er blevet omskrevet til ytringspli, ansvarlighed og respekt for forskellighed. Der er tale om en tavshed, der især presser sig på, når fjendens fjender er på spil, altså fjender af systemet, hvor islamister er de mest iøjnefaldende i dag. Sagen er, at man mister mælet, når der går kludder i ven/fjende-forhold, der styrer politisk orientering. Det vil jeg se på i det følgende i forbindelse med venstrefløjens markering af afstand til racisme og profilering af sin modstandsidentitet.

\section{Antiracisme: tre måder at argumentere på}

Jeg vil se på tre måder at argumentere på, der i en venstrefløjsoptik er antiracistisk. Venstreorientering er her forstået som en identitetsmarkør, der markerer en kritisk distance til systemet og højrefløjen. Tankegangen er, at systemet retter de ikke-konforme ind, hvorfor tavshed rummer et modstandspotentiale og borger for autenticitet. Her opererer man med et højrefløjstema om det tavse flertal, man forstår og taler på vegne af. Således kritiserer forfatteren Suzanne Brøgger i sin nytårskronik i Politiken (2011) knap 10 års VKO-styre i Folketinget, der har ledt til, at befolkningen er „banket på plads“, og at „kulturens folk“ enten er „fyret, intimideret til tavshed eller kedet ihjel af tidsånden“.

Når det er ven/fjende-skematikken, der styrer, hvad der er venstreorienteret, er det at være i opposition en kvalitet i sig selv, uanset hvem og hvad det så er, man ikke kritiserer. Derfor er man selektiv med hensyn til, hvad man bliver indigneret over, og hvad man ignorerer, og derudover er kritik ofte ude af proportioner. Amerikanske soldaters forbrydelser i Abu Ghraib-fængslet i Irak i 2006 vakte opstandelse og ikke mindst skadefryd, fordi det kompromitterede den amerikanske præsident Bush. Men reaktionerne er ude af proportioner sammenlignet med eksempelvis det folkemord, det islamistiske terrorregime i Sudan har begået på en million mennesker de seneste årtier, som ikke har vakt indignation. Heller ikke Robert Mugabes diktatur i Zimbabwe, der har dræbt flere afrikanere end apartheiddiktaturet i Sydafrika, har kunnet vække forargelse, ligesom Saddam Husseins diktatur i Irak kun blev fordømt, da Irak var allieret med USA. Hvis der er en årsag til den slags misforhold, er det, at disse regimer ikke var autoriserede fjender, 
men enten var fjendens fjender og dermed per definition ofre for vestlig imperialisme eller slet og ret uden for ven/fjende-radarens rækkevidde.

Denne evne til at udvælge, hvad man bliver indigneret over, er selvfølgelig ikke noget, der kun kendetegner venstreorienterede. Det bør heller ikke forstås som noget konspiratorisk. Sagen er derimod, at de måder, man orienterer sig på, sporer en ind i bestemte baner og dermed væk fra andre. I de seneste årtier har kulturelle sammenstød spillet en stigende rolle for politisk identifikation, hvilket for venstrefløjens vedkommende har indebåret, at etnicitet og religion har fået større gennemslagskraft end køn og seksualitet (Berman 2010:211; Bruce 2001: kap. 5; Tatchell 2007a, 2007b:19, 22; 2009).

Jeg vil se på tre argumentationsfigurer, der er med til at strukturere et felt for venstreorienteret modstandsidentitet, der finder udtryk i antiracismediskurser, og som udtrykker en stræben efter at gøre tavs ved at opfordre til selvcensur, dæmonisere modstandere og retsforfølge brud på politisk korrekt tavshed. Den første argumentationsfigur vedrører depolitisering gennem forskydning fra en problemstilling til en anden, der er lettere at have med at gøre, samt tilsløring. Her er temaet skiftet fra ret til moral. Det er tydeligt i forbindelse med karikaturkrisen, hvor man undgår angreb på ytringsfrihed, samtidig med at man undergraver den ved at opfordre til selvcensur. Resultatet har været tavshed maskeret som kosmopolitisk indstilling og god tone. Den anden argumentationsfigur handler om moralisering af politik og dæmonisering af modstanderen, hvor temaet er selvgodhed. Dette kan illustreres ved at se på, hvordan venstrefløjsidentitet profileres ved at moralisere den offentlige debat og stigmatisere modstandere. Eksemplet er igen karikaturkrisen, hvor man gennem sprogbrugen skaber et billede af dem, der forsvarer ytringsfrihed, som indskrænkede og anløbne. Den tredje argumentationsfigur berører, hvordan tolerance og censur afhænger af ven/fjende-forhold, hvilket belyses ved hjælp af racismeparagraffen, hvor venstrefløjen ikke er styret af værdier, men af ven/fjende-forhold. Grundet sin modstandsidentitet retter man sin kritik mod højrefløjens islamofobi og bruger racismeparagraffen som et middel til at censurere politiske modstandere, hvorimod man er tavs over for islamisters racisme og sexisme.

\section{Depolitisering gennem forskydning og tilsløring}

Når Jyllands-Posten bragte de 12 Muhammed-tegninger, var det, fordi flere forfattere og illustratorer havde følt sig truet i forbindelse med, at de havde tegnet eller skrevet noget, der var relateret til profeten Muhammed. Resultatet var, at de havde lagt bånd på sig selv, og det var denne selvcensur, avisen ville gøre opmærksom på. Således udtalte Flemming Rose, der var avisens kulturredaktør: 
Det moderne, sekulære samfund afvises af nogle muslimer. De gør krav på en særstilling, når de insisterer på særlig hensyntagen til egne religiøse følelser. Det er uforeneligt med et verdsligt demokrati og ytringsfrihed, hvor man må være rede til at finde sig i hån, spot og latterliggørelse (Rose 2005).

For store dele af venstrefløjen faldt den slags argumenter ikke i god jord. I en senere artikel i det amerikanske tidsskrift CounterPunch opsummerede Rune Engelbreth Larsen (2010), der var en af de markante kritikere af regeringen under karikaturkrisen, en udbredt holdning til kampen for ytringsfrihed ved at hævde, at det „ofte ikke er andet end en undskyldning for en 'ret' til at dæmonisere muslimer!“. Som det vil fremgå, er det et gennemgående træk ved venstreorienteredes indstilling til karikaturkrisen, at det gælder om at dreje fokus væk fra problematiske politiske sager og over mod andre sager, hvor man føler sig på sikker grund og kan profilere sin kritik af systemet ved at tale på vegne af undertrykte. Jeg vil se på forskydning baseret på præmissen om at være i opposition kombineret med goodwill over for islamister og diktaturer i Mellemøsten, der kommer til udtryk ved, at disse ikke spiller nogen rolle $\mathrm{i}$ optrapningen og håndteringen af krisen, altså tavshed. Ifølge Engelbreth Larsen (2010) var karikaturkrisen forårsaget af tre forhold i dansk politik. For det første ,den forøgede accept af dæmoniserende og antagonistisk retorik mod muslimer". Dernæst rettes kritikken mod regeringens manglende diplomatiske evner til at forhindre, at krisen eskalerede, og til sidst peges der på regeringen og mediernes ,stærkt patroniserende og arrogante approach til ambassadørerne fra muslimske lande“ i efteråret 2005 (Larsen 2010; egen oversættelse).

Forskydningen fra ret til moral ses tydeligt i forbindelse med den krise, Jyllands-Posten gav anledning til med sine Muhammed-tegninger. Efter flere danske imamers ihærdige lobbyarbejde i Mellemøsten lykkedes det at gøre tegningerne til en krise af globalt omfang. I forbindelse med denne krise fremførte venstrefløjen to argumenter. Det første argument var, at krisen ikke handlede om ytringsfrihed, men om moral: at flertallet behandlede et sårbart mindretal dårligt, hvorved vi skabte fjender, hvilket $\mathrm{i}$ anden omgang kunne tjene som forklaring på og reelt undskyldning for, at disse fjender lagde os for had. Det andet argument for, at krisen ikke handlede om ytringsfrihed, var, at der ikke var nogen, der anfægtede Jyllands-Postens ret til at offentliggøre tegningerne. Derimod gik kritikken på, at det hverken var klogt, ansvarligt eller hensynsfuldt. På baggrund af disse to forskydninger ville man kritisere avisen og VKO og fremstå som dialogsøgende, samtidig med at man undgik at komme på kollisionskurs med ytringsfrihed.

Den toneangivende holdning blandt jurister og meningsdannere på venstrefløjen var, at nok var ytringsfrihed vigtig, men det var moral også. Afsættet 
for at kunne moralisere var, at ytringsfrihed ikke er absolut, men derimod relativ i forhold til kontekst og hensyn til udsatte minoriteter. Derfor: „Y Yringsfrihed ja ... men ..." Med dette forbehold forsøgte man at forskyde det politiske perspektiv fra, at ytringsfrihed var under angreb, til et perspektiv, der handlede om, hvordan vi behandler muslimer, der er en forhånet gruppe grundet den populistiske islamofobi (Bredsdorff 2006). Forskydningen fra ret til moral set i forhold til krisens karakter, og hvad man bør gøre, kan skitseres således:

Ret og moral i forhold til karikaturkrisen

Krisens Selvom tegnerne bliver truet på karakter: livet, er der ikke tale om angreb på ytringsfriheden, men derimod om en reaktion mod de magtfuldes forhånelse af de magtesløse.

Blikket rettes mod stigmatisering af mindretal og tonen i debatten som den egentlige årsag til såvel tegningerne som de voldsomme reaktioner herpå.

Handlings- Fordi det er et spørgsmål om moral, anvisning: er en indskrænkning af ytringsfrihed ikke påkrævet, og derfor kan man omkostningsfrit forsvare den.

Man bør lægge bånd på sig selv og udvise dannelse, saglighed, ansvarlighed, selvcensur, etisk forsvarlighed samt anerkendelse af og respekt for etniske minoriteter.

Et gennemgående træk ved indignationen over tegningerne bestod ikke i, at nogen krænkede ytringsfriheden, eller i den selvcensur, der blev fremført som årsagen til at publicere dem. Det, man var indigneret over, var derimod, at de symboliserede et ønske om at håne en svag gruppe. For ytringsfrihed var ikke tiltænkt at beskytte de stærkes mulighed for at ringeagte de svage.

Det var noget, der kunne appellere til en ligheds- og oppositionssøgende venstrefløj. Men hvilken lighed? Tydeligvis ikke den, at man deler sig efter anskuelser. For der sker noget med lighed, når man orienterer sig i andre baner end højre/ venstre, dvs. i oppe/nede- og inde/ude-baner. Kultur har dannet rammen for det at være nede og ude, dvs. offer, og kultur definerer ens gruppetilhørsforhold og fordrer, at man friholdes fra kritik. I denne identitetspolitik bliver kultur gjort til det, der blåstempler udsagn og handlinger. For en kulturalistisk venstrefløj bliver de andres kultur identificeret med politisk progressivitet, der borger for, at det, de siger og gør, er på afstand af og derfor ubesudlet af magt. Denne dyrkelse af renhed er essentiel for en modstandsidentitet, hvilket har en tematisk lighed med radikal højreorientering, hvorfor det gælder om at have status af at være undertrykt som udsatte minoriteter eller det tavse flertal.

Forskydningen fra ret til moral er centralt hos historiker og mellemøstforsker Jørgen Bæk Simonsen fra Københavns Universitet, der skrev: „Det drejer 
sig slet ikke om rettigheder, men om almindelig høflighed - og den blev i dette tilfælde bevidst tilsidesat.“ Statsministeren burde „have slået et slag for, at medierne nøje overvejer, hvordan de skriver“, og „,det ville klæde den almindelige debat, hvis også medierne tog sig tid til at overveje, hvordan sproget bruges“ (citeret i Bredsdorff 2009:32).

Herefter kan nævnes flere venstrefløjsjuraprofessorer. Jurist Henning Koch fra Københavns Universitet var også med på forskydningstemaet og slog i lighed med Simonsen til lyd for god tone: „Umiddelbart har det ikke noget med ytringsfrihed at gøre. Det drejer sig om etik og klogskab." Herefter gik han over til at formane, at: „Ytringsfriheden bør bruges med respekt for andres religion og overbevisning. Gensidig tolerance og respekt er grundlæggende værdier, som vi alle bør værne om“" (citeret i op.cit.36, 144).

Og videre til jurist Jørgen Dahlberg-Larsen fra Århus Universitet, der sagde, at ,[y]tringsfriheden giver os ret brede rammer, men vores moral forhindrer os $\mathrm{i}$ med vilje at krænke andres følelser" (citeret ibid.).

Jurist Henrik Zahle fra Københavns Universitet fulgte i samme rille og indskærpede alle de forhold, man skal være bevidst om, før man ytrer sig på en måde, der kan tænkes at virke krænkende. Også her er forskydning afgørende, blot handlede det for ham ikke om høflighed, men om ,ansvarlighed, der indebærer, at man gør sig klart, hvem ytringen vil kunne nå frem til, gør sig klart, hvilken betydning den vil kunne have for disse, og hvilken betydning det kan få for en selv at ytre sig“" (citeret i op.cit.37).

Man skal med andre ord tænke sig ualmindelig grundigt om, før man ytrer sig, hvilket selvfølgelig er en opfordring til at tie, da ingen nogensinde vil være i stand til at kunne fremskaffe tilstrækkelig pålidelig information til at kunne honorere disse krav. Endelig kan nævnes et kulturradikalt koryfæ som forfatteren Klaus Rifbjerg, der, i anledning af udgivelsen af Flemming Roses bog Tavshedens tyranni (2010), ironiserede over dennes samt andres forsvar for ytringsfriheden. I tråd med forskydningslogikken tilføjede han: „Der er bare den hale ved det, at hele miseren er opstået pga. et psykoinfantilt eksperiment, der ikke har en skid med ytringsfrihed at gøre" (Rifbjerg 2010).

Som det fremgår af disse indlæg, er der en betydelig modvilje mod at forholde sig politisk til karikaturkrisen, hvorimod man har følt sig kaldet til at moralisere og til at mane til besindighed.

\section{Moralisering af politik og dæmonisering af modstanderen}

Politisk uenighed behøver ikke at indebære, at man udviser moralsk foragt over for dem, man er uenig med, eller vil lukke munden på dem ved at føre retssager 
imod dem. Men som vi har set i forbindelse med venstrefløjsdebattørernes indlæg under karikaturkrisen, har man lagt vægt på at forskyde sagens kerne fra politisk ytringsret til moralsk tavshedspligt. Dette er gået hånd i hånd med en dæmonisering af højrefløjen, som man tiltænker det værste. Her kan man i første omgang hæfte sig ved synet på Jyllands-Postens bevæggrunde for at offentliggøre tegningerne, som der ikke er høje tanker om. Jurist Eva Smith fra Københavns Universitet udtalte, at tegningerne var en ,krænkende provokation for provokationens skyld“, og at ,grænsen [for ytringsfrihed] bør gå ved ytringer, der har til formål at svine andre til“" (citeret i Bredsdorff 2009:30).

Information fortsatte i samme spor og tilføjede dumhed som en af de ting, der udmærkede Jyllands-Posten. Således hed det, at tegningerne var ,,bevidst provokerende og udfordrende“, og at man gjorde det „for provokationens egen skyld med et mediestunt, hvis begavelsesniveau ikke ligger højere end en opfordring til rituel afbrænding af nationalflag i ytringsfrihedens navn“" (citeret i op.cit.31).

Springer man nogle år frem, konstaterede Politikens chefredaktør Thøger Seidenfaden i en leder, at grundet det hjemlige politiske klima er vi endnu ikke parate til at give en undskyldning for karikaturkrisen, selvom det går fremad. Dog er det stadig sådan, at ,retten til at sige noget dumt på besynderlig vis [er] blevet drejet til en pligt" (Seidenfaden 2010b).

Ved at sige, at de to begivenheder er lige ubegavede, etablerer Information en ækvivalens mellem dem. Hermed er provokation lige så uacceptabelt som at brænde flag af, der er ledsaget af vold og hærværk, og det at gøre Danmark til et mål for terrorister er et passende modtræk til satire. Når man sidestiller disse forhold, er det, fordi de bliver læst ind i en ven/fjende-optik: Fjenden er systemet med dets stigmatisering af en udsat minoritet, der som offer ikke handler, men kun reagerer på provokationer og krænkelser. Derfor må den udsatte minoritet friholdes for kritik, og derfor er det heller ikke relevant at vurdere, hvorvidt terror er et passende modtræk til satire.

Temaet om forhånelse og dumhed som den drivende kraft bag tegningerne blev taget op af jurist og forfatter Maria Grønlykke. Hun modstillede de platte tegninger på den ikke mindre platte avis med den tænksomme Rushdie - en tænksomhed, der som bekendt ikke havde nogen formildende indvirkning på det iranske præsteskab. Grønlykke (2005) siger: „I det omfang Jyllands-Posten har haft tanker bag tegningerne, så var det kun et budskab til landets muslimer om, at 'I og jeres tro kan rende os noget så inderligt' - så meget for Allah og hans profet! Pur forhånelse, intet andet.“

Tilbage står, at ytringsfrihed skal bruges med eftertanke, hvilket hun kom ind på, da hun slog fast, at denne frihed handler ,om noget stort og betydningsfuldt. Det er en rettighed, som handler om at videregive et budskab, 'at offentliggøre sine tanker', som Grundloven siger" (ibid.). 
Hermed kommer man ind på det centrale tema om dialog versus forhånelse. Rifbjerg (2010) nævner, at diskussionen om ytringsfrihed er forloren, og journalist Georg Metz ynder at tale om hykleri. Det er, fordi man ikke er ,interesseret i dialog eller en fornuftig snak på humant grundlag og i ytringsfrihedens navn ... [derimod vil man] krigen og allerhelst hånd $\mathrm{i}$ hånd med de mest reaktionære $\mathrm{i}$ nationen“ (Metz 2010). Argumentet er ikke præsenteret som et angreb på ytringsfrihed, men på ytringsfrihedens binding til krig og reaktion frem for til fornuft og humanisme.

Der er ingen af de her nævnte, der søger at indskrænke ytringsfrihed. Deres forbehold går på, om man har noget betydningsfuldt at sige, og om man har orden i sine humanistiske akkreditiver. Har man ikke det, skal man ikke bruge sin ytringsfrihed, og under alle omstændigheder skal man kun bruge den med allerstørste omtanke. Men hvem skal afgøre, om ens tanker er værdifulde for offentligheden, og hvilke kriterier, der skal ligge til grund for den slags afgørelser? Det får man ikke noget bud på, og spørgsmålet bliver heller ikke stillet. Men det er næppe Jyllands-Posten og konsorter, for det er ikke alle, der kan adressere offentligheden på en ordentlig måde. Derfor er det nødvendigt med moraliserende formaninger fra besindige jurister og andre ansvarlige debattører, der forskyder karikaturkrisen fra én, der er politisk og handler om ytringsfrihed, til én, der er moralsk og handler om høflighed. Det er her, man bliver formanet om, at man skal tænke, før man taler, være opmærksom på sit sprog, være fornuftig, have fornemmelse for andres følelser, være høflig, hensynsfuld, ansvarlig, tilbageholdende, nuanceret og respektfuld. Det er ikke bare kvaliteter i sig selv, men også nødvendigt i en globaliseret verden, der fordrer et kosmopolitisk adfærdskodeks. Kritik er i orden, hvis det bliver gjort med omtanke, og man har gennemtænkt konsekvenserne. Forbeholdene fylder stadig mere, fordi grænsen mellem kritik og hån kan sløres så meget, at man hellere må lade være med at give lyd fra sig for at være på den sikre side. Altså tavshed.

Sammenfattende kan man sige, at der er nogle karakteristika ved denne måde at argumentere på, der står i skarp kontrast til en højre/venstreoptik: at uenighed er moralsk forkastelig, hvorfor opposition er illegitim, og at kritik er stødende og skal begrænses af lovgivning og selvcensur (Bawer 2009:26; Bruce 2001:76). Det er tydeligt, når man ser på de ord, der bliver anvendt, og hvor kontrasten til dialog, respekt og forståelse (det gode) er diktat, ringeagt og uvidenhed (det onde). De ord, man bruger, tåler ikke at blive sagt imod, og derfor er dissens illegitim. For skal man lade være med at opføre sig pænt og tænke, før man taler? Eller skal man være uopmærksom på sit sprog, ubegavet, ufornuftig og usaglig, uhøflig og ufølsom? Eller umoden, ignorant, ensidig og uansvarlig? At bruge den slags argumenter kendetegner en politisk kultur, hvor forskelle reduceres til en morali- 
serende indignation mellem godt og ondt, der undergraver det, man prædiker, altså dialog, tolerance og forståelse. For er man uenig, må man være styret af nedrige motiver, der overflødiggør samtale og gør konflikter uforsonlige.

\section{Tolerance og censur afhænger af ven/fjende-forhold}

I de sidste par årtier har multikulturalisme været et omdrejningspunkt for venstrefløjsidentitetspolitik, hvor det at være bundet til sin subkultur indikerer politisk progressivitet. Multikulturalisme refererer ikke bare til sameksistensen af flere kulturer, men også til, at man hverken kan eller bør kritisere andre i det omfang, det, de siger eller gør, kan føres tilbage til deres kultur. I den oplysningstradition, venstrefløjen er rundet af, plejede det at være omvendt: Kultur som skæbne var et reaktionært anslag mod individets frihed og emancipation i det hele taget. Men sådan er det ikke nu, fordi det ikke giver mulighed for at være i opposition. I stedet borger det at være minoritet for høj moral i modsætning til det at tilhøre majoriteten, der er konform og middelmådig (Bérubé 2009:11-12, 21, 28, 41, 84-6, 224-6, 245-6; Davies 2010:50). Denne modstandsidentitet har medført, at der er brede kredse på venstrefløjen, der udviser en tolerance over for islamister, fordi de som fjendens fjende kan bruges til at kritisere det, de ser som den konforme tidsånd præget af assimilation og intolerance. Kravet til majoritetssamfundet er at søge dialog, forståelse og konsensus frem for at være forudfattet, dogmatisk og antagonistisk, at have respekt for andres følelser og levevis, altså at være tolerant og åben frem for intolerant og snæversynet, samt at give plads til og anerkende forskellighed frem for, at alle skal skæres over én læst.

Men når moralske opfordringer er utilstrækkelige, må man ty til anstændighedens sidste bolværk: racismeparagraffen. Der er især to argumenter, man har ført sig frem med, for at bevare denne paragraf, der gør tavs. For det første sætter den grænser for tilsvining af svage grupper og plejer i den forbindelse et venstrefløjsimage. For det andet stadfæster den, at ord leder til handling, hvilket er lovens omdrejningspunkt.

Selvom grænserne for, hvad der kan accepteres, flytter sig over tid, hvilket vil sige, at synet på, hvad racisme er, også ændrer sig, er racismeparagraffen stadig et bolværk mod den værste tilsvining af udsatte og svage grupper. For eksempel hedder det i Politikens leder 5 . december 2010 i forbindelse med, at folketingsmedlem for DF Jesper Langballe har fået en dom for racisme: „Racismeparagraffen skal være den absolut yderste revle i en åben og fri offentlig debat om indvandringens omfang" (Politiken 2010). Dermed er paragraffen et værn mod ytringsfrihed, når denne bruges til at undertrykke dem, der i forvejen ligger ned, dvs. den forsvarer ånden i ytringsfriheden mod politisk pervertering. På den måde er 
racismeparagraffen en påmindelse om, at ytringsfrihed kun er legitim, når den bruges af dem, der ligger ned, mod dem, der er ovenpå. Offerideologi spiller en vigtig rolle her, fordi man som offer har ret til at blive friholdt fra kritik, af hvilken grund andre har en moralsk pligt til at være tavse om noget, de alligevel hverken kan eller er berettiget til at forholde sig til, nemlig det kulturelt særegne.

Når det gælder signalpolitik, er man optaget af at placere sig rigtigt i forhold til gældende ven/fjende-forestillinger. Det betyder at markere opposition til det konforme og de højreorienterede, fordi imagepleje vejer tungere end politiske principper og værdier. Et par eksempler kan illustrere dette.

I forbindelse med at det radikale islamistiske og eksplicit antidemokratiske parti Hizb-ut-Tahrir afholdt et møde i Det Kongelige Bibliotek, leverede Politiken i sin leder den 21. januar 2011 med overskriften ,Nyfascisme“ et solidt forsvar for ytrings- og forsamlingsfrihed. Selv dette parti, der med lederens ord er formørket, ultrakonservativt, reaktionært, frihedsfornægtende, antidemokratisk, antisemitisk, nyfascistisk og totalitært, skal have lov at ytre sig frit. For deres vanvid skal frem i lyset og imødegås i en åben debat med respekt for det åbne retssamfund. Men når andre danskere bruger deres ytringsfrihed til at kritisere og håne muslimer, er tolerancetærsklen en ganske anden. I lyset af Politikens leder halvanden måned tidligere om racismeparagraffen som ,,absolut yderste revle“ kan det undre, at avisen ikke ønsker at bruge lovgivningen til at gøre nyfascisterne tavse. Det må indebære, at Hizb-ut-Tahrir er mere moderat end Langballe og andre racismedømte medlemmer af Dansk Folkeparti. Da der ikke er noget sagligt belæg herfor, er det sandsynligt, at ønsket om at behandle nyfascisterne med åbenhed og dialog skyldes, at de markedsfører sig som ofre for systemets konformitet og højrefløjens hetz.

Et andet eksempel på signalpolitik er folketingsmedlem for Socialistisk Folkeparti Trine Pertou Machs blog på venstrefløjsportalen www.modkraft.dk. I påsken 2011 havde ungdomsafdelingen i Islamisk Trossamfund inviteret den canadiske islamist Bilal Philips til København - en mand, der er fortaler for, at homoseksuelle bør henrettes, og at mænd har ret til at slå deres hustruer, hvis de ikke opfører sig som ønsket. I den forbindelse blev der organiseret en moddemonstration. Selvom Mach beskriver Philips budskaber som ,det fuldstændigt modsatte af, hvad en solidarisk venstrefløj arbejder for", var det alligevel vigtigere for hende at markere modstand mod ,hele det borgerlige og højreorienterede sammenrend, som sandsynligvis vil være der og ligne en samlet front mod de af vores naboer, der deltager i mødet““ (Mach 2011). „De borgerlige er altså“, som journalist Bjarke Larsen (2011) bemærker, ,en langt vigtigere og farligere fjende end rabiate islamister. Tankevækkende." Men næppe overraskende, for denne signalpolitik har til hensigt at markere modstand mod de borgerlige. Derfor er det underordnet, hvem og hvad det så er, man støtter. 
Hvor bolværk er „damage control“, og signal er imagepleje, har påstanden om kausalitet mellem ord og handlinger altid været hovedargumentet for indgreb mod ytringsfrihed. Det var trumfkortet for Sovjetunionen og tredjeverdenslandes vedtagelse af FN's racismekonvention i sin tid, og det er også løftestang for multikulturalisme. Antagelsen er, at hvis man offentligt ikke bare truer, men også nedværdiger nogen på grund af deres „race, hudfarve, nationale eller etniske oprindelse, tro eller seksuelle orientering", som det hedder i racismeparagraffen, vil det opildne til had og hetz. Krænkelsen er ikke bare rettet mod bestemte grupper, men er politisk, i og med den truer den sociale orden og forrår samfundet.

Det er ikke klart, hvordan ord og handlinger hænger sammen. Men det har noget at gøre med, at højreradikale populister systematisk spreder løgne om svage og udsatte grupper. Det går især ud over muslimer, men homoseksuelle står også for skud. Konsekvensen er, at nogle kommer til at tro på det, hvorefter de ser sig i deres gode ret til at udøve vold mod dem, der er blevet lagt for had. Som advokat Pia Justesen (2010) siger: „Ord er ikke bare ord. Ord kan slå hårdt. Ord kan skabe virkelighed ... Hvis ord gentages tilstrækkeligt mange gange, risikerer de at blive opfattet som fakta." Der er to ting på spil her. For det første, at skellet mellem ord og handling er så sløret, at det berettiger til at forbyde særligt ondartede ytringer, fordi de kan slå hårdt og skabe virkelighed. Det er centralt for ethvert angreb på ytringsfrihed, at man udvisker skellet mellem krænkende ytringer og fysisk vold, således at man kan straffe meningstilkendegivelser, der opfattes som uacceptable. Et andet forhold, der er typisk for denne argumentation, er den elitisme, der kommer til udtryk i, at man nærer en begrænset tiltro til folks dømmekraft. Folk kan tilsyneladende bildes hvad som helst ind, hvis det bare bliver sagt tilstrækkeligt mange gange. Et eksempel på disse to forhold er en artikel af det Radikale Venstres næstformand Zenia Stampe (2010a). I denne argumenterer hun for racismeparagraffen ved at henvise til en af sine venner, der havde fået en blodtud, fordi han var bøsse. Hendes signalement af gerningsmanden var ikke, at han var født ond, men at han var blevet fyldt med løgne om homoseksuelle, der ægger til vold. Volden ligger faktisk lige om hjørnet, og der er folk derude, der bare venter på at øve vold mod minoriteter, hvis racismeparagraffen en dag skulle blive ophævet. Man ved ikke, hvad folk kan finde på, hvis ikke de får indprentet, at de skal vægte deres ord og være hensynsfulde.

For både Justesen og Stampe er problemet, at vi siden ,systemskiftet“ i 2001, hvor Venstre og Konservative dannede regering med støtte fra Dansk Folkeparti, har været vidne til en ondartet spiral, der består af følgende kausale kæde:

$$
\begin{aligned}
& \text { Løgn } \rightarrow \text { had } \rightarrow \text { splittelse } \rightarrow \text { diskrimination } \rightarrow \\
& \text { vold } \rightarrow \text { forfølgelse } \rightarrow \text { folkedrab } \rightarrow \text { krig }
\end{aligned}
$$


Zenia Stampe beskriver sammenhængen sådan: ,Løgne, der er blevet til had, og had, der endte i afstumpet vold. Racismeparagraffens formål er netop at forhindre denne negative spiral i at få frit løb“ (Stampe 2010a). I et senere debatindlæg nævner Stampe (2010b), at „løgne kan føre til had, og at had kan føre til splittelse, diskrimination, vold, forfølgelse, folkedrab og krig“. Så hvorfor nøjes med at gribe ind, når disse uhyrligheder er i fuld gang, frem for at tage det i opløbet ved at forbyde løgn? Også her er der to forhold på spil. For det første afhænger racismeparagraffens legitimitet af validiteten af den kausale kæde fra løgn til folkedrab og krig. Zenia Stampe argumenterer ikke for, at den holder, det antager hun blot. Denne kausale kæde lader til at være en universel argumentationsfigur de sidste 500 år, der går fra religiøs forfølgelse over totalitære regimers undertrykkelse af dissidenter til vore dages politiske korrekthed. For det andet tjener opbuddet af ulyksaligheder, løgn fører med sig, som et retorisk greb, der skal vise den glidebane, man kommer ud på, hvis man afskaffer racismeparagraffen, og den vil få katastrofale følger. Tanken er, at kan ulyksalighederne undgås med lidt omtanke og selvcensur, har man alt i alt betalt en billig pris. Sagen er, om det er folk som Bilal Philips, der skal udøve selvcensur, eller populistiske politikere, hvis udskejelser er arnestedet for løgne og had.

Ved at associere krænkende ytringer med vold, folkedrab og krig kan venstrefløjens antiracisme opnå tre ting. For det første fremmaner man en krænkelsesmentalitet, der går på, at etniske minoriteter i Vesten systematisk bliver lagt for had, stigmatiseret og hetzet imod. Det er i tråd med den strategi, Organisationen for Den Islamiske Konference (OIC) har ført sig frem med siden årtusindeskiftet. ${ }^{2}$ I denne strategi bliver muslimer fremstillet som ofre for amerikansk imperialisme og borgerlig konformitet. Ved at kriminalisere det, der kan udlægges som forhånelse og latterliggørelse af religion, kan man presse på for at begrænse ytringsfrihed. For det andet vender man op og ned på tolerancebegrebet, så det ikke længere er modtageren af en kommunikation, der skal udvise tolerance over for ytringer, man ikke bryder sig om, men den, der ytrer sig, der skal udvise agtpågivenhed for ikke at såre andres følelser (Rose 2010:399-400). Gør man det, er man ansvarlig for voldelige reaktioner, for den, der tyer til vold, er i virkeligheden selv et offer, der blot reagerer og derfor unddrager sig ansvar. Det gælder selvfølgelig kun i det omfang, volden begås af medlemmer af minoritets- eller subkulturer. For det tredje vender man op og ned på forholdet mellem racismeparagraf og ytringsfrihed, dvs. at paragraffen forsvarer denne frihed. Det er Stampes pointe (2010d), når hun siger, at ,racismeparagraffen [ikke] forhindrer den frie og åbne debat. Den beskytter mod hetz og hadefuld propaganda“. Rettigheder som minoritetsbeskyttelse og ytringsfrihed udelukker ikke hinanden, for ,, hadefulde ytringer bruges til at hetze andre til tavshed - og dermed knægte minori- 
teters muligheder for at deltage i den demokratiske samtale. Beskyttelse af minoriteter er en forudsætning for reel ytringsfrihed" (Stampe 2010e). Seidenfaden er inde på noget lignende, når han argumenterer for, hvorfor racisme er forkert set ud fra en ,etisk norm om ligeværdighed“(2010a). I første omgang har vi den onde spiral, der i Seidenfadens udgave drejer sig om, ,, at den hadefulde udgrænsning af grupper fører til marginalisering og måske senere udstødelse, isolering eller - i yderste konsekvens - udryddelse af hele grupper“. Han fremstiller altså følgende kausale kæde:

$$
\text { Had } \rightarrow \text { marginalisering } \rightarrow \text { isolering } \rightarrow \text { udstødelse } \rightarrow \text { udryddelse }
$$

I anden omgang er racismeparagraffen sat til at „beskytte den norm om alle menneskers fundamentale ligeværdighed, der er selve grundlaget for alle de politiske og menneskelige rettigheder“ og dermed også demokratiet og ,,samfundets sammenhængskraft og sociale orden“ (ibid.). I denne argumentation bliver formel ytringsfrihed i kombination med racismeparagraffen lig med reel ytringsfrihed.

Tanken med racismeparagraffen er at slå en kile ind i denne onde spiral. Ifølge Stampe er „retten til fri racisme ... højreradikalisternes vådeste drøm“ (Stampe 2010b), og hun opfordrer derfor Dansk Folkeparti til at ,sige det, som det er, at man gerne vil have fripas til at svine bestemte befolkningsgrupper til““ (Stampe 2010a). Hun beskylder videre Trykkefrihedsselskabet for, at de „skamrider ytringsfriheden til at promovere deres islamofobiske paranoia under falsk varebetegnelse" (Stampe 2010c). Retten til fri racisme står over for retten til at være fri for de højreradikales løgne og had, der er de første skridt mod holocaust - denne gang med muslimer i offerrollen. Derfor også den ofte anvendte term ,islamofobi“, som Metz (2010) omtaler som ,,vore dages udgave af jødeforagten - denne åbenbart uudryddelige trang til at hæve sig op ved at nedstøde andre“. Over for islamofober og populister har vi en passiv befolkning, de kan modellere efter forgodtbefindende. Det er derfor, folk skal beskyttes mod det $\mathrm{i}$ sig selv, der er receptivt over for denne propaganda, hvilket også er en beskyttelse af demokrati, orden og sammenhængskraft. Derfor er censur både nødvendig og progressiv.

\section{Ven/fjende-logik og venstrefløjens goodwill over for islamister}

I de senere årtier er venstreorienteret modstandsidentitet sprunget ud som en kulturrelativistisk hybrid af defaitisme, radikalisme og reaktion, der i tre henseender har berøringsflader med højreorientering.

For det første kulturalisme, der betyder, at man taler inden for en identitetspolitisk diskurs, der i modsætning til en nationalt baseret kulturalisme idolise- 
rer andetheden, fordi den markerer afstand til systemet. Hermed bliver den/det fremmede en modstandsfigur. For det andet antimodernitet, der signalerer, at man er skeptisk over for modernitet, fremskridt, individualisme, rationalitet mv., fordi man ikke længere er orienteret i emancipatoriske baner, men har overtaget en reaktiv og skeptisk dagsorden, der plejede at være forbeholdt konservative. For det tredje offermentalitet, der indebærer, at man taler på vegne af dem, der ikke selv kan tale. Til forskel fra konservative populister, der taler på det tavse flertals vegne, ønsker man at være talerør for tavse mindretal, og i lighed med dem ser man fællesskaber af ofre som en autentisk kraft, der er udgrænset af systemet.

Disse temaer har appelleret til venstrefløjen, fordi de passer ind i den ven/ fjende-matrix, der strukturerer dens udsyn. Denne ven/fjende-matrix danner rammen om politisk intensitet, der kredser om kollektivisme, solidaritet og eksklusion som nødvendige for stærk gruppeidentitet. Af samme grund er det at bekræfte denne matrix vigtigere, end at de værdier, man forsvarer, er udskiftet med deres modsætning. Det, der ansporer venstreorienteredes goodwill over for islamister, er fremmaningen af deres fælles fjende, hvilket skyldes, at det, der virkelig tæller, er at dyrke sin modstandsidentitet. Kritikken rettes mod moderne vestlig livsstil med dens individualisme og rodløshed samt amerikansk imperialisme og zionisme. Mere specifikt er fjendebilledet systemets konformitet og de højreorienteredes aggressivitet. Recepten er, at fjender kritiseres ubønhørligt, og at man geråder ud i tavshed, når det er fjendens fjender, der gør noget uacceptabelt.

Prisen for denne kulturalistiske identitetspolitik - der er den nationalkonservative kulturalismes spejlbillede - har været tavshed, når det gælder principiel stillingtagen til ytringsfrihed og at kritisere fjendens fjender, når de foretager sig noget, der strider mod det, der plejede at være ens værdier. I begge tilfælde er der tale om, at tavshed og konformitet er to sider af samme sag, også selvom tavsheden er pakket ind i eftertænksomhed og kosmopolitisk dannelse.

\section{Noter}

1. §266 b indgår i straffelovens kapitel 27 under freds- og ærekrænkelser. Den stammer fra 1939 og er efterfølgende blevet ændret i 1971, 1987, 1995, 2000 og 2004, både hvad angår ,den kriminaliserede handling og den beskyttede gruppe“. I sin nuværende form lyder den:

„Den, der offentligt eller med forsæt til udbredelse i en videre kreds fremsætter udtalelse eller anden meddelelse, ved hvilken en gruppe af personer trues, forhånes eller nedværdiges på grund af sin race, hudfarve, nationale eller etniske oprindelse, tro eller seksuelle orientering, straffes med bøde eller fængsel indtil 2 år.

Stk. 2. Ved straffens udmåling skal det betragtes som en særligt skærpende omstændighed, at forholdet har karakter af propagandavirksomhed.“

2. OIC er en organisation, der tæller 57 muslimske lande, og som bl.a. i over 10 år forsøgte at få FN til at kriminalisere religionskritik. På OIC's website er der links til rapporter om 
intolerance, diskrimination, islamofobi og ,hate crimes“ mod muslimer: http://www.oicoci.org/page_detail.asp?p_id=168 og http://www.islamophobia-watch.com/. For en diskussion af islamofobi $\mathrm{i}$ forhold til Jyllands-Postens tegninger: http://www.islamophobia-watch.com/ islamophobia-watch/category/danish-cartoons.

Søgeord: karikaturkrisen, moralisere, racisme, tavshed, ven/fjende, venstrefløj

\section{Litteratur}

Bawer, Bruce

2009 Surrender: Appeasing Islam, Sacrificing Freedom. New York: Doubleday.

Berman, Paul

2010 The Flight of the Intellectuals. New York: Melville House.

Bérubé, Michael

2009 The Left at War. New York \& London: New York University Press.

Bredsdorff, Nils

2006 De respektables blinde øje. Kronik i Jyllands-Posten 18. april.

2009 Tiden råber på satire: Venstrefløjen, de kulturradikale og muhammedkrisen.

Roskilde: Skriftserie fra Roskilde Universitetsbibliotek, nr. 52.

Bruce, Tammy

2001 The New Thought Police: Inside the Left's Assault on Free Speech and Free Minds. New York: Three Rivers Press.

Brøgger, Suzanne

$2011 \quad$ Nytårssyner. Kronik i Politiken 1. januar.

Davies, Jon Gower

2010 A New Inquisition: Religious Persecution in Britain Today. London: Civitas.

Grønlykke, Maria

2005 Æbler blandet i pærerne. Kronik i Information 20. december.

Justesen, Pia

2010 Ord skaber virkelighed. Kronik i Berlingske Tidende 17. juni.

Larsen, Bjarke

2011 Pinlig tavshed om venstrefløjsvold. Information 4. maj.

Larsen, Rune Engelbreth

2010 The Danish Cartoon Affair. Counterpunch 24.-26. september. http:// www.counterpunch.org/2010/09/24/the-danish-cartoon-affair/.

Mach, Trine Pertou

2011 Det yderste højre besøger Nørrebro. http://www.modkraft.dk/blogs/trine-pertou$\mathrm{mach} /$.

Metz, Georg

$2010 \quad$ Frihed - til rent hykleri. Information 8. maj. 
Politiken

Leder. 5. december.

2011 Leder. 21. januar.

Rifbjerg, Klaus

2010 Aldrig har PH's navn være misbrugt som i disse dage. Politiken 7. oktober.

Rose, Flemming

2005 Ytringsfrihed. Jyllands-Posten, Kulturweekend, 30. september.

2010 Tavshedens tyranni. Århus: Jyllands-Postens Forlag.

Seidenfaden, Tøger

2010a Derfor er racisme forkert. Politiken 19. juni.

2010b Så er vi tre: Den svære kunst at sige undskyld. Leder i Politiken 19. oktober.

Stampe, Zenia

2010a Racismeparagraffen: En vigtig grænse. Politiken 18. juni.

2010b Højrefløjen vil have fri hetz. Politiken 9. august.

2010c Ytringsfrihed: Trykkefrihedsselskabet sejler altså stadig under falsk flag. Politiken 17. august.

2010d Ytringsfrihed: Trykkefrihedsselskabets tilståelse. Politiken 24. august.

2010e Folket til politikerne: Nej tak til fri racisme. Politiken 12. oktober.

Tatchell, Peter

2007a Why has the Left gone Soft on Human Rights? The Independent 22. marts.

2007b Their Multiculturalism and Ours. Democratiya 8:16-26. http:// dissentmagazine.org/democratiya/article_pdfs/d8Tatchell.pdf.

2009 Not All Cultures are Equally Valid and Commendable. The Independent 3. november. 
